\title{
The Secret Behind Human Breathing
}

\author{
Seethalakshmy Nagarajan* \\ Yogic Power Practitioner, UK \\ Submission: April 20, 2017; Published: June 07, 2017 \\ *Corresponding author: Seethalakshmy Nagarajan, Yogic Power Practitioner, UK, Email: sitatvs2007@gmail.com
}

\section{Opinion}

Almost $99 \%$ of the mass of the human body is made up of six elements and they are oxygen, carbon, hydrogen, nitrogen, calcium, and phosphorus. Only about $0.85 \%$ is composed of another five elements which are potassium, sulphur, sodium, chlorine, and magnesium. The remaining elements are trace elements. Thus, most of the mass of the human body is oxygen, and breathing has been the main activity of the human body to sustain all other bodily functions. Let us look deep into this matter. When we breathe, we inhale oxygen and exhale carbon dioxide. A depletion of carbon dioxide can result in chest tenderness and throbbing pain, high or low blood pressure, angina, hypertension and tachycardia. Asthmatics quickly can overcome asthma assaults, by reinstating carbon dioxide levels, which expands bronchial pathways. If the inter- exchange of oxygen and carbon dioxide is done correctly while practicing the correct breathing technique, then it will balance the $\mathrm{pH}$ level of the body, the equilibrium gained by this practice will affect the nervous system directly awakening in this way the parasympathetic branch, this will in turn make the mind calm and open, and a sense of well being will ensue.

On the other hand, altering the oxygen and carbon dioxide ratios in the blood stream persuades the thought process to slow down. The tempo of the respiration is associated with different moods of bodily activity and different emotional states. Practicing the right breathing technique can get rid from obesity, heart tribulations, hypertension and etc. In addition, it is an enormous support for the physical and spiritual refinement desirable for this path. Exercises, sexual acts or even thoughts and emotional states such as apprehension, distress, irritation, paranoia and so forth, intensify the pace of breath and can change it dangerously. This is why in yoga practices we could see that they will always diligently keep the breath under control. For one to have healthy and motivating experiences in life, it is required to hold and sustain the pranic energy (or Prana) within the body. Prana, also known as the life force, is the ultimate energy form of the universe. In order to retain this energy, one has to be initiated by a realised Guru who has the control over the Pranic energy.
Common Yoga teachers can just lead a person to theoretical approaches and gain the most out of the practices taught but not the real ancient yogi's experiences. To attain the real experiences of Yogis, one has to be guided by a Siddha (one who has attained enlightenment) or a Rajayogi (one who has perfected the art of Rajayoga). According to Siddhas, once the pranic energy is sustained by a person only then the path of realising the static dormant energy, Kundalini will be opened wide and can be aroused with the help of the realised Guru. A Realised Guru is defined as, a Guru who possess siddhic powers (the total control over life force energy, 5 elements of life), Divine Wisdom and has attained perfection. Only a perfect Siddha with Divine abilities shall lead a person to the right path of breathing and reveal the secrets behind it. To make it clearer, the Kundalini is a Divine static energy which is dormant at the Muladhara (Root Chakra), at the base of the spine. The pranic energy is all over the body in the form of 3 vital breaths, namely Ida, Pingala and Sulumna, which keeps the bodily functions together. This is why it is impossible to realize kundalini and utilize it correctly without sustaining pranic energy in the body as they are connected to each other. The Kundalini must be awakened by a realised Guru to aid in the path of Self-realisation or God-realisation, whichever chosen by the aspirant.. This is the reason why many misleading facts on kundalini awakening and so on are found because it has not been assisted and awakened under proper supervision of a realised Guru especially the one who has attained complete experience of it. To be truthful, when the Kundalini is awakened after successfully controlling the pranic energy, only then the energy can be utilised to bring forth tremendous changes on human health, wealth and success in life. Not only can a person achieve all the abilities mentioned above but one can also enjoy internal harmony, improved digestion, enhanced sleep, superior memory and concentration. Bad temper and physical exhaustion will in due course disappear.

Acquiring this art is the most sophisticated task and cannot be dreamt of without the help of a true Guru. This art has to be mastered through an expert and the real need of the hour is to 
be able to practise this ancient art in a manner to suit the needs of current century. As such, this definitely has to be under the guidance of The World Leading Siddha of Yoga, Divine Wisdom and Meditation Practice, His Divine Grace Yoga Jnana Sitthar Om Sri Raja yoga Guru. His Divine Grace has mastered the art of controlling the pranic energy and Kundalini awakening through Raja yoga pathway and extensively researched the art for 27 years to identify the exact mechanism by which the art can be imparted effectively upon people from all walks of life. As a result of this tireless and exhaustive research, His Divine Grace advocates aspirants from around the world the concept of sustaining the pranic energy (life force energy) within one's body, for the past 21 years. The Kundalini awakened in this manner is named the Yogic power, which indeed is a powerful energy that promises GREAT improvement in overall heath and calmness of mind. This will eventually develop into a sense of constant well being, ecstasy and bliss which will be supported by sturdy nerves and equanimity of the mind. This has been proved by hundreds of thousands of practitioners who have awakened their Kundalini energy under the guidance of His Divine Grace . The best part is, each individual has great control over his or her own Yogic power and their testimonials can be shared upon request.

The most important fact that needs to be taken note is that Kundalini exists in all human beings in an inactive state and we are indeed very lucky because we are living in the presence of His Divine Grace, who is the One and the Only Guru in this current era who has the ability to impart the true essence of Raja yoga, tailored to suit modern living. Every lesson in life involves a teacher, the teacher can be a Christian, Muslim, Hindu, Buddhist, Sikh, Atheist and so on. Most importantly, there is the need to have the right teachers to master the lessons correctly. Maths, Science, English, Geography, Dance, Martial Art, etc involve teachers. When these subjects require teachers to be explained, imagine mastering the art of breathing, sustaining the pranic energy and realizing the Divine Kundalini energy. Obviously this subject requires a teacher (REALIZED GURU) to impart the knowledge and transform us into a real full potential human being. Therefore, it is worthwhile with not confusing oneself with self-made interpretations but GRANT oneself the wonderful opportunity to awaken this energy and utilize it to its fullest potential.

\section{Your next submission with Juniper Publishers will reach you the below assets}

- Quality Editorial service

- Swift Peer Review

- Reprints availability

- E-prints Service

- Manuscript Podcast for convenient understanding

- Global attainment for your research

- Manuscript accessibility in different formats ( Pdf, E-pub, Full Text, Audio)

- Unceasing customer service

Track the below URL for one-step submission https://juniperpublishers.com/online-submission.php 